\title{
Security Measures on Things and the Nature of Criminal Law of Non-conviction Based Corrupt Assets
}

\author{
Wei Lei \\ School of Criminal Justice, \\ Shanghai University of Political Science and Law.
}

\begin{abstract}
It is necessary to avoid the hidden loss of non-conviction based corrupt assets due to the lag of domestic law and to avoid the lawful rights and interests of the persons involved in the process of recovering the non-conviction based corrupt assets in order to provide sufficient domestic law basis for the recovery of non-conviction based corrupt assets. Criminal law provides substantive explanation to establish the security of the article is divided into the interpretation of the basic principles of criminal law and to establish the behavior of the person involved in the conviction and the relative separation of assets involved in the separation of criminal procedures ideas through the introduction of the future judicial interpretation.
\end{abstract}

Keywords-Security measures; Undecided crime; Corrupt assets; Criminal law

\section{INTRODUCTION}

In September 2016, the Chinese government and the Canadian government signed the Agreement on the Sharing and Return of Recovered assets in Canada, which was the first special agreement concluded by China in the field of proceeds of crime and China has made landmark progress in the development of corrupt assets [1]. Considering At home and abroad on the recovery of non-convicted corrupt assets in the field of theoretical research, the relevant research is mainly from the international judicial assistance or criminal procedural law point of view in the field of relevant substantive law and especially in the field of domestic criminal substantive law Research. The urgent need is to deepen the recovery of non-convicted corrupt assets of the domestic criminal law research.

\section{CONFLICT BETWEEN CONFISCATED CORRUPT ASSET AND CURRENT CRIMINAL LAW}

The more pressing issue is to resolve the multilateral framework or the bilateral agreement on the recovery of corrupt assets and the existing Conflict of criminal law in view of the need for coordination with the relevant criminal procedural law in China's current foreign criminal law.

Supported by The National Social Science Fund of China (15BFX042), and Shanghai University of Political Science and Law Collaborative Innovation Team Project, and "B\&R" Security Series of Project, Shanghai University of Political Science and Law Research Fund Project (No. 2014XJ06)

\section{A. Conflict between the Confiscation of non-conviction based corrupt assets and the Principle of Legally Prescribing Punishment}

The third article of the criminal law China provides that: "the law expressly provides for criminal acts, in accordance with the law conviction and punishment; the law does not expressly provided for criminal acts and shall not be convicted." This is the cornerstone of modern criminal law criminal law of the Chinese criminal law expression. The principle of the principle of legality was revised in 1997 , which is a major symbol of China's criminal law scientific and modern development. The whole process of criminal law adhere to the principle of the crime of legality is an unshakable iron law. It is a criminal substantive law and has dual value and significance: First, the Chinese criminal law provides for a number of other principles such as the crime of punishment and the principle of consistency and the principle of equality before the criminal law can be derived from the principle of legality. There is no clear provisions of the criminal law that criminal charges and criminal liability shall not exist and as a result of the crime of criminal penalties and other non-penalties shall not exist. Twelfth:' without the people's court in accordance with the law, no person shall be convicted. The fundamental value of the existence and operation of the criminal procedure law is to ensure the correct implementation of the criminal law, in which the primary value is to ensure the correct implementation of the principle of legality, at the same time in the criminal procedure law it also embodies the principle of presumption of innocence [2]. From this point of view, the sharing and return of corrupt assets must be consistent with the principle of legality, otherwise it will lose the most reliable legal basis in China's domestic law. However, it is regrettable that the sharing and return of corrupt assets in China's domestic law and the principle of a legally prescribed punishment for a crime so that it need to be addressed and resolved.

The crime of corruption assets recovery pending legal premise still cannot be separated from the basis of conviction but some content of multilateral framework and bilateral agreements Chinese join in and Chinese criminal law is not the same. There are signs of violation of the principle of legality. If there is sufficient evidence of corruption assets that are 
shared to convict disposal, it will encounter a conflict with the principle of legality: some multilateral framework of bilateral agreements with Chinese join in and China criminal law is not consistent. For example, China in current criminal law to the bribery provisions is inconsistent with the provisions of Chinese added more "United Nations Anti-corruption Convention", especially the dual conviction mode China current criminal law for the crime of corruption and bribery provisions of the criminal law caused by corruption and bribery of qualitative differences so that China proposed share and return requirements may be rejected. China's current criminal law based on the identity of the alleged criminals belonging to the national staff or non-state staff of the crime of corruption and bribery is divided into different conditions and penalties for the outcome, showing a two-fold mode of conviction. China's current criminal law based on the identity of the alleged criminals belonging to the national staff or non-state staff of the crime of corruption and bribery is divided into different conditions and penalties for the outcome, showing a two-fold mode of conviction. This kind of corruption model of corruption and bribery is based on the distinction between the subjective identity of the alleged offender and the criminal policy requirement of carrying out the individual treatment of the crime of bribery and bribery of different persons. China's current criminal law based on the identity of the alleged criminals belonging to the national staff or non-state staff of the crime of corruption and bribery is divided into different conditions and penalties for the outcome, showing a two-fold mode of conviction. This kind of corruption model of corruption and bribery is based on the distinction between the subjective identity of the alleged offender, and it is the criminal policy requirement of carrying out the individual treatment of the crime of bribery and bribery of different persons. According to their own national conditions and criminal justice practice to do with the characteristics of the institutional arrangements [3]. However, China's accession to the "United Nations Convention against Corruption" and other relevant multilateral or bilateral criminal justice agreement, the corruption and bribery recognition and treatment did not make the defendant because of the identity of different recognition criteria and the outcome of the punishment of the institutional arrangements, which show the identification and punishment of corruption and bribery unified integration of the conviction model. If the principle of the principle of legality should be insisted on the understanding of China's domestic law, there should be a clear conflict between the two modes and it needs to be bridged in a reasonable and legal way.

\section{$B$. The conflict between sharing and returning corrupt assets and Article 64 of the Criminal Code}

If the idea of sharing and returning corrupt assets and the principle of legality has a conceptual conflict, it will be only abstract. The existence of Article 64 of the present criminal law in China directly leads to a conflict of norms with the sharing and return of corrupt assets, which is more direct, more urgent and more unavoidable.

Article 64 of the current Criminal Law of the People's Republic of China stipulates that "all property of the offender's illegal gains shall be recovered or ordered to be returned; the legitimate property of the victim shall be returned in time; the contraband and the property of the person used for the crime shall be confiscated. Property and fines should be turned over to the state treasury and shall not be misappropriated and self-handling. "It should be considered that the provisions of Article 64 of China's existing criminal law from the perspective of national standpoint and the Chinese legislative tradition has a certain legitimacy and rationality. The Chinese criminal law insists on the state position that does not compromise with the crime so that we should punish the perpetrators in an all-round way, increase the type of punishment for the criminal property and declare the significance of the state position. From the perspective of Chinese legislative tradition, there are more historical traditions in the history of China, such as "no nationality" and "copying". But in the world today, the general confiscation of article 59, which is similar to Chinese criminal law, has been very rare. Laws are mostly similar to the special confiscation or recovery of proceeds of article 64 of the Chinese Criminal Code. From the provisions of Article 64 of the Criminal Law of China, the use of "all property", "should be paid", "should be promptly returned", "all turned over to the state treasury", "cannot be misappropriated and self-handling" and so very clear and even severe expression. It will share and return the corrupt property in the current criminal law in the legitimacy of the space compressed to almost zero.

Therefore, this section concludes that if the legalization of the distribution and return of corrupt property is carried out only if it is difficult to make the necessary changes to the existing criminal law, it is only through a reasonable interpretation of the criminal law. The introduction of the concept of security measures is that we should establish the security system of things to the recovery, share and return corrupt assets in order not to violate the current criminal law reasonable interpretation and positioning.

\section{AN ANALYSIS OF THE NATURE OF THE SECURITY MEASURES OF OBJECTS AND THE NATURE OF CORRUPT ASSETS IN CHINA 'S CRIMINAL LAW}

The introduction of the concept of security measures to criminalize the criminal assets of the crime of interpretation and positioning, the main starting point is because: the penalty needs to be compatible with the responsibility, or must be compatible with the responsibility of the law and security sanctions are not compatible with the responsibility problem [4]. In the traditional criminal law legislation or theory, the security measures are mainly for the criminals and the establishment of the criminal law system, "the state prevents crime in order to achieve the purpose of controlling crime, maintaining social order, through legislative form. The sum of all kinds of corrections and treatment measures aim at eliminating the criminal risk of the person, rather than making a legal negation or legal judgment of the person's conduct, against the offender and the person at risk of the crime. "[5] The types of security that have existed or are in existence in China are: reeducation through labor, compulsory medical treatment, compulsory detoxification, school, education, shelter, shelter, leave, and drunkenness. In the whole view, the use of the concept of development and international perspective, for the non-conviction based corrupt assets set up 
on the security system of objects, it is not only an effective docking of non-convicted corrupt assets to recover, share and return the objective requirements, but also in criminal law Using the less controversial theoretical framework to solve the problem of criminalization of corrupt assets without conviction.

\section{A. Security measures on things : On the Nature of Criminal Law of Non - convicted Corrupt}

The recovery, repayment and return of the non-conviction based corrupt assets are defined as the security disposition of the object, which has the following prominent value of the criminal law theory and the practical significance of the criminal justice practice:

Firstly, the non-convicted of corruption of the assets of the recovery, sharing and return is defined as the security of the matter and it is able to pursue the responsibility of the people and the state of the object of the appropriate separation and make reasonable and legitimate arrangements to be more so as well to meet the needs of modern society. In the general traditional view or system, insisted on the first conviction and punishment and the first conviction after the confiscation of the relevant property, will be confiscated property as a follow-up responsibility for the follow-up approach, which in modern society is to protect human rights. The purpose of nature has its own significant rationality. In modern society, many crimes and even extremely serious crimes are difficult to achieve after the first conviction, the first conviction after the confiscation of confiscated property, such as modern terrorism, transnational drug crime and transnational corruption.

Secondly, the non-convicted of corruption of the assets of the recovery, sharing and return to define the security of the object, the application of an independent criminal law system and the criminal procedure system, will be conducive to the responsibility of the suspects of corruption, which is conducive to corruption The fundamental prevention. Corruption crime is a typical greedy crime, greedy and unscrupulous to grab the interests of corruption is the fundamental driving force [6]. We should convict the corruption of the assets of the recovery, share and return to the security of the matter, in the crime of corruption. We should deal with the responsibility before the first corrupt assets to be disposed of to reduce the survival of criminal suspects and cut off the psychological support of criminal suspects, which will be conducive to the pursuit of corruption suspects, persuasion, repatriation, transfer and other personal responsibility to pursue .In this way we make a strong rule of law show that potential corrupt elements to dispel fantasy, which is conducive to the fundamental prevention of corruption.

\section{B. Overseas Prosecution and Counterfeiting Mechanism and Realization of Criminal Law Provisions}

The construction of an external traitor-splitting mechanism, including the sharing, recovery and return of non-conviction based corrupt assets, is an ideal mode of simultaneous development of international judicial cooperation and domestic legislation. On the one hand, more multilateral or bilateral judicial cooperation mutual aid agreement or special agreements such as the sharing and return of assets to be recovered by the agreement. On the other hand, we should develop new legislation on domestic legislation and revise the old law and other development.

The development of new legislation on domestic legislation, the revision of the old law and other development. But in the field of criminal law, the latter may be more difficult. It is reported that China has the "International Criminal Judicial Assistance Law" including in the 2015 legislative preparatory projects and has completed the proposed draft, entered the stage of consultation [7]. But with a more closely related criminal law, the modification is more difficult. In the case of criminal law has not yet changed, the construction of the existing provisions of the criminal law does not conflict with the sharing, recovery and return of non-convicted corrupt assets rules so that the more feasible path is to deepen the theoretical proof of the material security principles and applicable rules and the practical explanation of the criminal law in the criminal judicial practice.

Firstly, in theory, we should deepen the argument on the principle of security and the application of the rules. First of all, in the theory of criminal law has always been on the theoretical positioning of the security of the existence of a unified and dual debate, that is, security and punishment in the criminal law is separate provisions or one, is the different types of responsibility or the same way of responsibility. Thus, the need for in-depth analysis of the object of security and punishment, especially the confiscation of property punishment, the relationship between the fine penalty. From the current stage of social development and theoretical are serves in China, the security system will be more and more independent of the position, without modifying the criminal law, through the theoretical full argument. We could start from the security system of things to proceed and open up with the Chinese characteristics of the sharing and return of corruption asset system to explore. Secondly, the principle of setting up the security disposition, that is, whether the security precautions should follow the principle of legally prescribed punishment for a specified crime or the establishment of a separate legal principle and the need for in-depth analysis of the principle of setting up security measures. The traditional legal point of view of the crime of death has been three hundred years of history is fixed to the criminal law also has nearly two hundred years of history, as the feudal monopoly of the sharp weapons, the principle of legality of criminal law worthy of the cornerstone of modern criminal science. However, in the new area of information globalization, the principle of legality of the original criminal law will not be able to explain and deal with the new era of the subject, and social stage of natural development of new theoretical principles and rules. It is like the dilemma of classical physics after the birth of quantum mechanics: it is not that classical physics is no longer science, is abandoned, but the original classical physics and the applicable rules are more finely determined However. The principle of punishment will be able to live in harmony with the principle of legality and punishment in the future of China's legal system.

Secondly, we should use substantive interpretation of the relevant provisions of the criminal law to rationalize the interpretation in the practice of criminal justice. The method of 
substantive explanation is one of the more active methods of criminal law in recent years, which is more suitable for the establishment and realization of the security measures. Use the substantive interpretation method to explain the rationalization of Article 64 of the Criminal Law, combined with the theoretical types of the security of the object, in-depth analysis of the confiscation, recovery, sharing, return and other types of theoretical rational positioning of the interpretation. Specifically, it is: 1 . The "recovery" and "confiscation" in the provisions of article 64 of the Criminal Law do not have the same criminal law value and applicable rules: the recovery should be applied to the form of movable property suspected of corruption assets, confiscation should be applied to the form of real estate suspected of corruption assets. 2, "Criminal law" provisions of the "illegal income" does not fully correspond to the composition of the crime, but also can cover the proceeds of non-conviction. 3. The "illegal gains" stipulated in Article 64 of the Criminal Law need to be reconciled with the relevant provisions of the Code of Criminal Procedure and need to be confirmed by an independent criminal justice procedure, and cannot be attached to the criminal justice process against human beings.

\section{CONCLUSION}

To sum up, the corresponding proposal is: Article 64 of the Criminal Code, "all turned over to the state treasury", can be interpreted as a real share of the shares to share and return the domestic procedures of corruption, rather than the final legal outcome. Through the domestic criminal law enforcement procedures to confirm, recover, confiscate suspected corruption assets, according to different criminal justice program design, you can consider setting the relevant notice, rights objection, error relief and other procedures, efforts to both achieve effective Punish corruption and fully protect the ideal state of human rights.

\section{REFERENCES}

[1] Wang Minyan: "China and Canada signed on the sharing and return of assets to be recovered by the agreement," Legal Daily "September 23, 2016.

[2] Li Xiujuan: "United Nations Convention against Corruption and China's criminal law comparative research", China University of Political Science and Technology in 2006 doctoral thesis.

[3] Cao Hailei: "Criminal Law", Southwest University of Political Science and Law 2010 doctoral thesis.

[4] Zhang Mingkai: "On the confiscation of criminal law", "jurist", No. 3, 2012, p. 67.

[5] Dong Zhenyu: "China's security measures to", Jilin University 2009 doctoral thesis

[6] The original Lirong: "the purpose of the Criminal Procedure Law", "Journal of Shandong University (Philosophy and Social Sciences Edition)", No. 5, 2008, p.

[7] "International Criminal Judicial Assistance Law (draft)" expert consultation will be held successfully ", China Social Science Network, http: //www.cssn.cn/st/st_zthd/201503/t20150316_1548375.shtml, Visit time: March 17, 2017. 